\title{
Effect of Application Method and Rate on Residual Efficacy of Mefenoxam and Phosphorous Acid Fungicides in the Control of Pink Rot of Potato
}

Raymond J. Taylor, Julie S. Pasche, and Neil C. Gudmestad, Department of Plant Pathology, North Dakota State University, Fargo, ND 58105

\begin{abstract}
Taylor, R. J., Pasche, J. S., and Gudmestad, N. C. 2011. Effect of application method and rate on residual efficacy of mefenoxam and phosphorous acid fungicides in the control of pink rot of potato. Plant Dis. 95:997-1006.

Experiments were conducted to examine the effectiveness of rate and method of phosphorous acid application for controlling pink rot of potato (Solanum tuberosum) caused by Phytophthora erythroseptica. Replicated small-plot and replicated split commercial field trials were established in commercial production fields in Minnesota from 2006 to 2009. Fungicides were applied in-furrow at planting, or as one, two, or three foliar applications via ground sprayer, irrigation system (chemigation), or fixed-wing aircraft. Phosphorous acid efficacy was compared to mefenoxam, the fungicide commonly utilized to manage pink rot, either by determining natural infections in the field or by inoculating eyes of harvested tubers using a mefenoxam-sensitive and -resistant isolate of $P$. erythroseptica via postharvest challenge inoculation. In replicated small plot trials, both in-furrow and two foliar applica-

tions of mefenoxam controlled tuber rot in the field, and significantly controlled tuber rot in storage. Phosphorous acid also reduced tuber rot in the field when applied two or three times to the foliage. Although phosphorous acid was ineffective when applied in-furrow, one, two, and three foliar applications and a postharvest application of phosphorous acid controlled mefenoxam-sensitive and -resistant isolates of $P$. erythroseptica during storage for 187 days, while mefenoxam failed to control the resistant isolate. In replicated split commercial field trials, two aerial applications of phosphorous acid were as effective as three applications in reducing pink rot incidence in tubers inoculated postharvest. Three aerial applications were as effective as three chemigation applications in replicated split commercial field trials in 2008, but provided significantly greater protection than chemigation in 2009 .
\end{abstract}

Pink rot, caused by the homothallic oomycete Phytophthora erythroseptica Pethybr., is one of the most destructive soilborne tuber diseases affecting potato (Solanum tuberosum L.). The pathogen is widely distributed, and is a persistent problem in most potato growing regions of the world. Since the first report of its occurrence in North America in 1938 (4), pink rot has emerged as one of the most important diseases affecting potato production in the United States, causing serious losses in the field and postharvest in storage $(3,20,42,46)$. Because $P$. erythroseptica is a ubiquitous soilborne pathogen, infections can occur throughout the growing season. Disease development is favored by warm, moist conditions $(4,25,26,45)$ and often is enhanced during periods of heavy rainfall, in low-lying portions of fields, and in areas of poorly drained soil. Although on rare occasions it may attack above ground portions of the plant causing leaf spots, petiole blights, stem decay, and wilting, $P$. erythroseptica is primarily a pathogen of the below ground tissues. The pathogen can infect the root and basal portions of the stem as well as stolons and tubers $(8,16,39,40)$. Tuber infections generally occur via the stolon, but when conditions are favorable, zoospores will attack tubers through eyes and lenticels or at sites where the periderm has been wounded or damaged $(25,27,39,45,46,55)$. Infected eyes turn a dark brown to black color and infected tuber tissue becomes rubbery and watery. Depending upon the cultivar, tuber tissue develops a light cream to salmon pink color when exposed to air for a short period of time $(16,25)$.

Extended survival of $P$. erythroseptica as oospores in the soil and infected plant debris make pink rot difficult to control $(16,55)$. Additionally, the pathogen is transferred readily from field to field

Corresponding author: Neil C. Gudmestad,

E-mail: Neil.Gudmestad@ndsu.edu

Accepted for publication 27 March 2011.

doi:10.1094/PDIS-09-10-0694

(C) 2011 The American Phytopathological Society on contaminated seed (13) and is capable of infecting a variety of crop and weed hosts (16). Most potato cultivars currently grown in North America are considered to be susceptible to P. erythroseptica $(35,44,50)$; therefore, disease management traditionally has focused on modifying cultural practices. Such strategies generally target conditions that favor infection, including planting in well drained soils, avoiding excessive irrigation, timing vine kill and harvest to promote proper skin set, as well as altering tuber handling procedures to reduce tuber wounding during harvest, postharvest transportation, and storage. Soil populations of $P$. erythroseptica in heavily infested fields can be reduced by rotating to a nonsusceptible crop for a minimum of 4 years (16), or less when combined with conservation tillage practices $(37,38)$. Implementation of such management techniques can reduce pink rot incidence in many cases; however, fungicide applications usually are utilized to supplement these strategies.

The phenylamide fungicide metalaxyl (Ridomil) and its Renantiomer metalaxyl-m, mefenoxam, have proven to be highly effective in controlling $P$. erythroseptica. Initially released as metalaxyl in 1977, the fungicide provided excellent control of most oomycete pathogens, but resistance soon developed and now is widespread throughout the $P$. erythroseptica population in North America (52). Although mefenoxam still can be used effectively to control $P$. erythroseptica populations predominantly composed of sensitive strains $(31,32,36,51,53,56)$, the continual spread of resistance reaffirms the need to investigate alternative fungicides capable of managing populations resistant to mefenoxam. Although the first phosphonate fungicide, fosetyl-Al (aluminum tris- $O$-ethyl phosphonate), was released commercially at approximately the same time as metalaxyl, phosphonates only recently have been investigated as potential control agents of oomycete fungi. Phosphorous acid (phosphonate or phosphite) has proven effective against a number of foliar and soilborne diseases caused by pathogens in the order Peronosporales, many of which are caused by Phytophthora spp. $(11,33)$.

Phosphorous acid $\left(\mathrm{H}_{3} \mathrm{PO}_{3}\right)$ is a structurally simple compound, but its mode of action appears to be complex and is not completely understood. Studies have demonstrated that it affects the pathogen 
directly by inhibiting mycelial growth, suppressing sporulation and germination, influencing membrane metabolism and phosphorylation reactions $(5,10,11,17-19,22,33,47)$, and indirectly by stimulating the host plant's defense responses $(11,15,16,21,22,34,47)$. Both direct and indirect actions may be involved in most pathosystems, but evidence suggests that direct antifungal activity probably is more important $(11,21,43)$. It is now believed that fosetyl-Al and other alkyl phosphonates break down to form phosphorous acid within plant tissue (33), and most evidence points to phosphorous acid as the component providing the in vivo antifungal activity associated with the phosphonate fungicides. Phosphorous acid also has been shown to inhibit mycelial growth in vitro $(10,17,18)$.

Like mefenoxam, phosphorous acid is translocated systemically within the plant, but unlike mefenoxam, the spectrum of biological activity against Phytophthora spp. is narrower, demonstrating low activity against some species and high activity against others (11). The fungicide has proven to be useful in controlling late blight tuber rots $(12,24,28,29)$. Such effectiveness against $P$. infestans has stimulated interest in determining the efficacy of phosphorous acid against $P$. erythroseptica as well, prompting several recent research studies examining its potential for pink rot control. Results obtained in early greenhouse and field experiments suggested that foliar applications of phosphorous acid could provide effective pink rot control, but these results were highly variable, and as a consequence it was concluded that phosphorous acid should not be relied upon to control the disease (56). More recently, experiments to determine the ability of phosphorous acid to control tuber infections in the field found that the fungicide was ineffective when applied in furrow at planting (1). Results obtained in subsequent studies, however, suggested that foliar applications of phosphorous acid could be an effective addition to a pink rot management program $(1,23,24,29)$. One 3-year study (24) conducted over multiple locations recorded significant reductions in pink rot incidence following challenge-inoculations of tubers harvested from plants that received three foliar applications of phosphorous acid. That same study reported significant reductions in pink rot severity with two foliar applications of phosphorous acid but not pink rot incidence. Although significant differences in disease incidence were noted, levels of disease control were relatively small as disease incidences of phosphorous acid-treated tubers still ranged from 66 to $88 \%$.

Previous work also suggested that phosphorous acid potentially could provide protection during storage. Complete control of pink rot (zero tuber infection) after 30 days in storage was obtained when tubers were treated with three commercial formulations of phosphorous acid within 1 to $3 \mathrm{~h}$ following inoculation with $P$. erythroseptica (23). Significant pink rot control also was obtained when phosphorous acid was applied within $6 \mathrm{~h}$ of inoculation (29). Tuber infections did occur in that study, with disease incidences ranging from 3 to $29 \%$ in the phosphorous acid treatments 14 days after inoculation. Other experiments (24) demonstrated residual efficacy of phosphorous acid up to 21 days after harvest. However, the effectiveness of the fungicide differed with location in some instances. Although the results obtained in these earlier experiments varied, they generally indicated that phosphorous acid can be effective in controlling tuber rot caused by $P$. erythroseptica. It remains unclear whether phosphorous acid fungicides will provide residual control of pink rot in storage beyond 30 days postharvest. In addition, all previous work with this class of fungicides for pink rot control has been done in small research plots and not under potato grower managed conditions.

The current study was undertaken to provide additional information regarding the use of phosphorous acid to control pink rot. The specific objectives of this research were to compare the timing and application method of foliar applications of phosphorous acid, examine residual fungicide efficacy during extended storage periods, and determine effectiveness against a mefenoxam-resistant isolate of $P$. erythroseptica. These studies included direct comparisons of the effectiveness of phosphorous acid and mefenoxam under replicated small plot conditions and also examined phosphorous acid efficacy under commercial potato production conditions and application methods. The earlier work referenced above assessed the effectiveness of phosphorous acid in controlling pink rot in Maine, Idaho, and the Pacific Northwest. The experiments described here represent the first extensive evaluation of phosphorous acid efficacy for pink rot control in the upper Midwest.

\section{Materials and Methods}

Application rate, timing, and residual fungicide efficacy. Replicated small plot trials to compare fungicide application rate, timing, and residual disease control were conducted under center pivot irrigation near Park Rapids, MN. These plots, situated in designated areas of commercial potato production fields, were planted in early May from 2006 through 2009 using certified seed of the cultivar Russet Burbank obtained from seed potato producers in North Dakota and Minnesota. Trials were established using whole and cut seed tubers planted at $0.3-\mathrm{m}$ spacing in four $7.6-\mathrm{m}$ rows, $0.9 \mathrm{~m}$ apart. An experimental unit consisted of 0.003 ha treated with fungicide each year. Data were collected from paired middle rows.

In 2006 and 2007, natural endemic inoculum of P. erythroseptica in field soil with a history of pink rot was augmented to enhance disease pressure and assess the effect of the fungicide treatments on pink rot development, with the cooperation of the collaborating growers. Cultures of $P$. erythroseptica mefenoxamsensitive isolate 266-2 were initiated in plastic culture dishes containing $17 \mathrm{ml}$ of $10 \%$ clarified V8 juice (CV8) agar medium (100 $\mathrm{ml} \mathrm{V8} \mathrm{juice,} 1 \mathrm{~g} \mathrm{CaCO}_{3}$ centrifuged at 7,000 RPM for $5 \mathrm{~min}$ using a Sorvall RC5C centrifuge to remove pulp, $15 \mathrm{~g}$ agar, $900 \mathrm{ml} \mathrm{de}-$ ionized $\mathrm{H}_{2} \mathrm{O}$ ). Prior to infestation, cultures were incubated at $25^{\circ} \mathrm{C}$ in the dark for 28 to 32 days to allow for oospore production and maturation. The contents of the culture plates were mixed with sterile, deionized $\mathrm{H}_{2} \mathrm{O}$ at a concentration of 40 plates liter ${ }^{-1}$, and processed in an electric blender into a uniform slurry containing agar, mycelium, and oospores. The mixture was sprayed in-furrow via a planter-mounted sprayer at the equivalent rate of 1.97 plates $\mathrm{m}^{-1}$. In-furrow fungicide treatments were sprayed simultaneously via a different outlet nozzle. In 2006, additional inoculum was prepared as described above and the soil was infested a second time 14 days after planting by spraying the slurry mixture on the soil surface and immediately covering it during the hilling operation. This postplanting sidedress infestation was not performed in 2007. In 2006 and 2007, fungicide efficacy was assessed by determining the percentage of tuber rot at harvest. Soil was not infested with P. erythroseptica in 2008 and 2009, as fungicide efficacy was evaluated via postharvest challenge inoculations. In all experiments, treatments were replicated four times within a randomized complete block design (RCBD).

In the replicated small plot trials preformed from 2006 to 2009 , mefenoxam (Ridomil Gold 4EC 47.6\% mefenoxam; Syngenta Crop Protection, Inc., Greensboro, NC; or Ultra Flourish $25.1 \%$ mefenoxam; Nufarm Americas, Inc., Burr Ridge, IL) was applied in-furrow at planting or as combined in-furrow and sidedress applications (Table 1). In these trials, an experimental unit was 0.003 ha. A mixture of mefenoxam plus mancozeb (Ridomil MZ, 64.0\% mancozeb; 3.9\% mefenoxam; Syngenta Crop Protection, Inc., Greensboro, NC) or phosphorous acid (Phostrol, mono- and dibasic sodium, potassium, and ammonium phosphates $53.6 \%$; Nufarm Americas Inc., Burr Ridge, IL) was applied as foliar sprays (Table 1). In-furrow fungicide treatments were applied with a ground sprayer at a water volume rate of 75 liters ha- ${ }^{-1}$ under $90 \mathrm{kPa} \mathrm{CO}_{2}$ pressure, and sidedress and foliar treatments were applied at a rate of 187 liters ha $\mathrm{h}^{-1}$ at $172 \mathrm{kPa}$ in the replicated small plot studies. Cultural practices recommended for irrigated potato production in the region were implemented throughout the growing season. In all years, tubers were harvested in early- to mid-September, 1 to 4 days after plants were killed by mechanical flailing. Harvested tubers were inspected for damage, pink rot, or other disease symptoms. Disease-free tubers were placed into storage for 2 weeks at $15^{\circ} \mathrm{C}$ and $90 \%$ relative humidity, after which tubers were stored at $10^{\circ} \mathrm{C}$ until inoculation trials were conducted. 
Comparisons of phosphorous acid application methods and frequency. Large-scale split plots were assigned to commercial potato production fields in west-central Minnesota during the 2008 and 2009 growing seasons. Irrigated potato circles planted with Russet Burbank were split, and each field was considered a replication of paired treatments. Trials comparing application of phosphorous acid (Nuphate, mono- and dibasic sodium, potassium and ammonium salts of available phosphate $36 \%$, soluble potash $7 \%$, ammoniacal nitrogen 5\%; Nufarm Americas) either via air, through the irrigation system (chemigation) or two versus three aerial applications of the fungicide were conducted (Table 1). Two versus three applications of phosphorous acid made by fixed-wing aircraft were compared in 12 split commercial fields (seven fields in 2008, five in 2009); aerial versus chemigation application methods also were compared in nine replicated split commercial fields (six fields in 2008 and three in 2009). An experimental unit consisted of 160.6 ha treated with fungicide. Treatments were applied at 47 liters $\mathrm{ha}^{-1}$ with fixed-wing aircraft, and chemigation application water volume rate varied between 25,700 and 63,460 liters $\mathrm{ha}^{-1}$. Tubers from each half (experimental unit) of a split circle were harvested using standard industry equipment and segregated by treatment during placement into commercial storage facilities. In order to eliminate potential interference from drift during aerial and chemigation applications, only tubers of the same cultivar collected from nearby fields not receiving mefenoxam or phosphorous acid applications served as controls. Control tubers produced in non-fungicide-treated fields were grown from the same seed source as the tubers produced in fields receiving fungicide treatments. All fields also had a similar soil type and cropping history. All fields were managed by cooperating growers using agronomic practices typical for the region. Harvested tubers were inspected for damage or disease symptoms, held for two weeks at $15^{\circ} \mathrm{C}$ and
$90 \%$ relative humidity, and subsequently stored at $10^{\circ} \mathrm{C}$ until inoculation trials were conducted.

Postharvest challenge inoculations. Fungicide efficacy was assessed by inoculating tubers following harvest. Sporangia were induced to form in cultures of $P$. erythroseptica mefenoxam-sensitive isolate 266-2 and mefenoxam-resistant isolate 217-1 following procedures used in earlier studies (49-51). These isolates currently are held in the collection of N. C. Gudmestad at North Dakota State University. The isolates were grown in culture plates containing clarified $10 \%$ V8 juice agar. After 3 days' incubation in an environmentally controlled chamber $\left(20 \pm 1^{\circ} \mathrm{C}\right)$ in the dark, 5-mmdiameter disks containing mycelium and agar were removed from the margin of the colonies and placed in culture plates containing autoclaved clarified $10 \%$ V8 juice broth. The broth cultures were incubated in the dark in an environmentally controlled chamber at $20 \pm 1^{\circ} \mathrm{C}$ for 3 days. Broth was removed from the plates, the mycelial mats were rinsed twice with sterile deionized $\mathrm{H}_{2} \mathrm{O}$, and the mycelium was resuspended in $10 \mathrm{ml}$ of autoclaved, filtered soil extract $\left(10 \%\right.$ soil from a potato field in deionized $\left.\mathrm{H}_{2} \mathrm{O}\right)$. Cultures were incubated in an environmentally controlled chamber $\left(20 \pm 1{ }^{\circ} \mathrm{C}\right)$ under constant illumination of eight Sylvania F20T12/CW lamps, and sporangial formation occurred within 36 to $48 \mathrm{~h}$. Soil extract was removed from the plates, and the mycelial mats were rinsed twice with sterile deionized $\mathrm{H}_{2} \mathrm{O}$. The mycelium was resuspended in $10 \mathrm{ml}$ of sterile deionized $\mathrm{H}_{2} \mathrm{O}$, and zoospore release was stimulated by chilling cultures in the dark at $10 \pm 1^{\circ} \mathrm{C}$ for $1 \mathrm{~h}$ followed by a warming period in the dark at $20 \pm 1^{\circ} \mathrm{C}$. Inoculum concentration was determined with a hemacytometer and adjusted to $2 \times 10^{4}$ zoospores $\mathrm{ml}^{-1}$ with autoclaved, deionized water. Zoospore suspensions were held in the dark at 8 to $10^{\circ} \mathrm{C}$ until inoculations were carried out, generally within $60 \mathrm{~min}$.

Table 1. Methods and rates of mefenoxam and phosphorous acid application in 2006, 2007, 2008, and 2009 field experiments evaluating control of pink rot caused by Phytophthora erythroseptica in potato tubers

\begin{tabular}{|c|c|c|c|}
\hline Year (trial type) ${ }^{\mathrm{w}}$ & Treatment $^{\mathrm{x}}$ & Application method and timingy & Application rate (g a.i. ha $^{-1}$ ) \\
\hline \multicolumn{4}{|c|}{2006 (replicated small plot) } \\
\hline & Nontreated & & \\
\hline & Phosphorous acid & In-furrow & 8,766 \\
\hline & Phosphorous acid & 3 foliar & 8,766 \\
\hline & Mefenoxam & In-furrow & 213.5 \\
\hline & Mefenoxam & 2 foliar & 112.0 \\
\hline \multicolumn{4}{|c|}{2007 (replicated small plot) } \\
\hline & Nontreated & & \\
\hline & Mefenoxam & In-furrow & 213.5 \\
\hline & Phosphorous acid & 2 foliar & 8,766 \\
\hline & Phosphorous acid & 3 foliar & 8,766 \\
\hline \multicolumn{4}{|c|}{ 2008/2009 (replicated small plot) } \\
\hline & Nontreated & $\ldots$ & $\ldots$ \\
\hline & Mefenoxam & In-furrow & 213.5 \\
\hline & Mefenoxam & In-furrow & 427.0 \\
\hline & Mefenoxam & In-furrow & 213.5 \\
\hline & & Sidedress & 213.5 \\
\hline & Mefenoxam & In-furrow & 213.5 \\
\hline & & Tuber initiation & 89.7 \\
\hline & Mefenoxam & 2 foliar & 89.7 \\
\hline & Phosphorous acid & Tuber initiation & 8,766 \\
\hline & Phosphorous acid & 2 foliar & 8,766 \\
\hline & Phosphorous acid & 3 foliar & 8,766 \\
\hline & Phosphorous acid & 10 days postharvest & $284^{z}$ \\
\hline \multicolumn{4}{|c|}{ 2008/2009 (replicated split commercial fields) } \\
\hline & Nontreated & $\ldots$ & \\
\hline & Phosphorous acid & 2 aerial & 8,766 \\
\hline & Phosphorous acid & 3 aerial & 8,766 \\
\hline & Phosphorous acid & 3 chemigation & 8,766 \\
\hline
\end{tabular}

\footnotetext{
${ }^{\text {w }}$ The experimental unit was equal to 0.003 ha in replicated small plot trials in 2006, 2007, 2008, and 2009 and 160.6 ha in split commercial fields in 2008 and 2009.

${ }^{x}$ Phosphorus acid applied as Phostrol (small plot trials) or Nuphate (commercial split fields), mefenoxam in-furrow applied as Ultraflourish, mefenoxam foliar applied as Ridomil Gold 4EC or Ridomil Gold MZ, chlorothalonil applied as Bravo Weather Stik.

${ }^{\mathrm{y}}$ Foliar applications applied at tuber-initiation (1 application), 14 (2 applications) and 28 (3 applications) days later where applicable.

${ }^{z}$ g a.i. metric ton ${ }^{-1}$.
} 
The effects of rate and timing of mefenoxam and phosphorous acid applications on pink rot development were assessed by challenge-inoculating tubers with either the mefenoxam-sensitive or -resistant isolate of $P$. erythroseptica. The residual efficacies of the fungicides from replicated small plot trials were assessed seven times at approximately 1-month intervals. The effects of chemigation and aerial applications of the fungicides from replicated split commercial field trials were evaluated by challenge-inoculating tubers with the mefenoxam-sensitive isolate of the pathogen. For each challenge inoculation trial, disease-free tubers (140 to $190 \mathrm{~g}$ ) with apical eyes free of soil and having an intact periderm were selected at random from each replication/treatment. Test tubers were allowed to acclimate at ambient temperature $\left(22 \pm 2^{\circ} \mathrm{C}\right)$ for 24 to $48 \mathrm{~h}$ then were placed in plastic moist chamber boxes $(33 \times$ $24 \times 12 \mathrm{~cm}$ ) lined at the bottom with two paper towels. Tubers were inoculated on each of three apical eyes with $10 \mu \mathrm{l}$ of the zoospore suspension, and then were covered with four layers of paper towels moistened to saturation with deionized water. Chamber
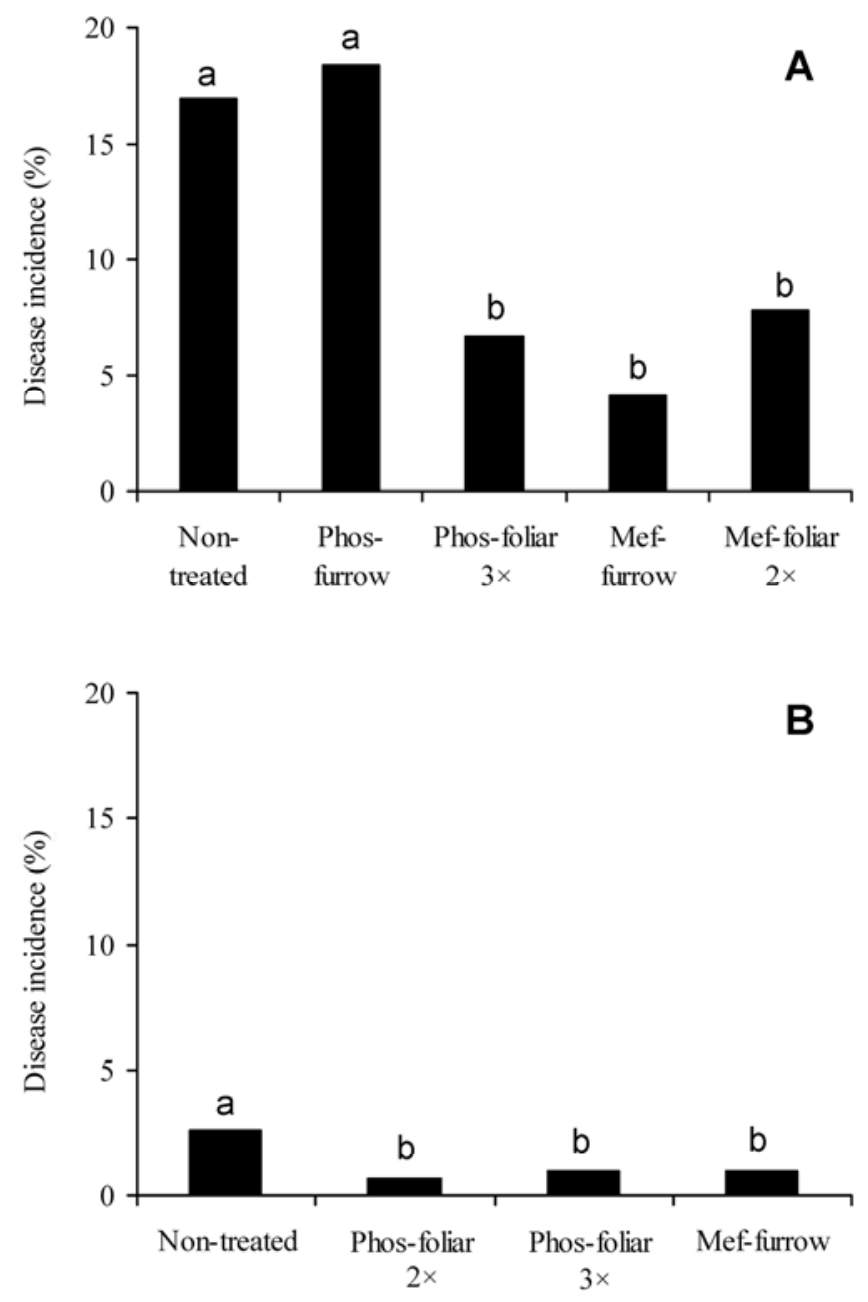

Fig. 1. Disease incidence (percent rot at harvest) of potato tubers grown from nontreated plants and plants treated with phosphorous acid or mefenoxam in replicated small plot research trials in 2006 (A) and 2007 (B). Treatments included: phosphorous acid in furrow (Phos-furrow), foliar applications at tuber initiation and 14 days post-tuber initiation (Phos-foliar $2 \times$ ), foliar applications at tuber initiation, 14 days post-tuber initiation, and 28 days post-tuber initiation (Phos-foliar $3 \times$ ) or mefenoxam in-furrow (Mef-furrow), foliar applications tank-mixed with chlorothalonil at tuber initiation and 14 days post-tuber initiation (Mef-foliar $2 \times$ ). Phosphorous acid was applied at the rate of 8,766 g a.i. ha-1. Mefenoxam was applied in-furrow at a rate of $214 \mathrm{~g}$ a.i. ha- ${ }^{-1}$ and as a foliar treatment at a rate of $112 \mathrm{~g}$ a.i. ha- ${ }^{-1}$ with chlorothalonil $\left(1,260 \mathrm{~g}\right.$ a.i. ha- $\left.{ }^{-1}\right)$. All in-furrow and foliar treatments were applied with 75 and 187 liters ha- $^{-1}$ of water, respectively. Treatment means with the same letter are not significantly different according to Fisher's protected least significant difference test $(\alpha=0.05)$. boxes were covered to establish high humidity to promote infection, arranged as a RCBD, and incubated in the dark for 9 days at an ambient temperature of 22 to $25^{\circ} \mathrm{C}$. Experiments were carried out as two separate inoculation trials each consisting of four replications of 10 tubers for a total of 80 tubers per treatment per year.

Disease assessments. In 2006 and 2007, disease incidence was quantified in the field by assessing the proportion of rotted tubers recovered at harvest; pink rot incidence (PR) was determined as follows: $\mathrm{PR}=$ (weight of diseased tubers/weight of diseased tubers + weight of healthy tubers) $\times 100$. For postharvest challenge inoculations conducted in 2008 and 2009, in both replicated small plot trials as well as replicated split commercial fields, disease development was quantified following protocols similar to those used in earlier studies (44,49-51). Tubers were removed from moist chambers and bisected through the axis from the sites of inoculation on the apical buds to the basal stem end. Split tubers were covered with moist paper towels and incubated at $22 \pm 2{ }^{\circ} \mathrm{C}$ for approximately 20 to $30 \mathrm{~min}$ to enhance the development of the pink discoloration diagnostic of $P$. erythroseptica infection. Infected tubers were counted and the percentage of infected tubers, or disease incidence (I), was calculated as (number of diseased tubers/number of inoculated tubers $) \times 100$. Disease severity was estimated by measuring the maximum depth $(D)$ of rotted tissue from the point of inoculation and a penetration rate $(P)$ was calculated: $P=D / T$ where $T$ is time in days after inoculation. Disease incidence was converted to percent disease control $(C)$ using the formula $C=$ [(disease incidence of nontreated control - disease incidence of treatment)/disease incidence of nontreated control] $\times 100$.

Data analysis. One-way analyses of variance (ANOVA) with replication and treatment as sources of variation were performed to determine if differences existed in disease incidence at harvest among fungicide treatments in replicated small plot trials conducted in 2006 and 2007. Levene's test for homogeneity of variance (HOV) was performed on postharvest tuber inoculation disease incidence and control data from residual efficacy trials conducted in 2008 and 2009 to ensure that data could be combined for further analysis (30). A two-factor ANOVA was performed on these data with mefenoxam isolate sensitivity and fungicide treatment as main effects. HOV also was evaluated for replicated split commercial field trials to ensure that variances were equal for all fields where treatments were compared. Postharvest tuber challenge inoculation data from all replicated split commercial field trials conducted to evaluate chemical application rate, timing, and the residual efficacy of the fungicides were analyzed using a oneway ANOVA with replication and treatment as sources of variation. All analyses were performed within PROC GLM of SAS. Fisher's protected least significant difference test was used for mean separation in all analyses $(\alpha=0.05)$.

\section{Results}

Application rate, timing, and residual fungicide efficacy. Pink rot was observed in tubers harvested in 2006 and 2007 from the replicated small plot trials that had been infested with $P$. erythroseptica. In 2006, tuber rot incidence in nontreated tubers was nearly seven times greater than the level of rot obtained in 2007. This finding probably reflects differences in propagule concentration as the soil was infested twice in 2006 but inoculum was incorporated into the soil only once the second year of the study. Significant reductions in tuber rot were recorded at harvest with foliar applications of phosphorous acid and mefenoxam, and with in-furrow mefenoxam applications, when compared to the nontreated control in $2006(P=0.0004)$ and $2007(P=0.0156)$ (Fig. 1). In 2006, when phosphorous acid was applied in-furrow, disease incidence did not differ significantly from nontreated tubers (Fig. 1A), so this treatment was excluded from the 2007 trial. However, reductions in disease incidence were similar with three foliar applications of phosphorous acid and with both in-furrow and two foliar applications of mefenoxam in 2006. Although incidence of pink rot recorded at harvest was generally lower in 2007, two or three foliar applications of phosphorous acid and an in-fur- 
row application of mefenoxam all provided significant reductions in disease compared to the nontreated control (Fig. 1B).

The time intervals (days after harvest) at which tuber challenge inoculations were performed differed by 1 to 8 days between 2008 and 2009 in the replicated small plot field trials (Table 2). Across all dates, Levene's test of HOV indicated that variances were homogeneous for 8 of 10 fungicide treatments; therefore, data were combined across evaluations at each time period. Treatments with nonhomogeneous variances include mefenoxam in-furrow $(P=$ $0.0013)$ and two foliar applications of mefenoxam $(P<0.0001)$. Results obtained in postharvest challenge inoculations of tubers produced in replicated small plot trials performed in 2008 and 2009 (Table 2) supported those obtained for field infections in the replicated small plot trials performed in 2006 and 2007 (Fig. 1). Pink rot incidence in nontreated tubers inoculated with the mefenoxam-sensitive and -resistant $P$. erythroseptica isolates ranged from 16.3 to $38.8 \%$ and 16.3 to $36.3 \%$, respectively, throughout the 6-month duration of storage evaluations (Table. 2). The main effects of mefenoxam sensitivity of the $P$. erythroseptica isolate and fungicide treatment were significant at all tuber challenge-inoculation dates (Table 3). A significant interaction also was observed between these main effects at all dates except 124 days after harvest.

All fungicide applications reduced disease incidence, significantly in most instances, throughout the storage period when tubers produced in replicated small plots were challenge-inoculated with the mefenoxam-sensitive isolate of $P$. erythroseptica (Table 2). Few significant differences existed in the level of protection provided among mefenoxam and phosphorous acid treatments. However, two and three foliar applications, or a single postharvest application of phosphorous acid tended to perform better than other treatments, although these differences were not always significant (Table 2). The ability of $P$. erythroseptica isolates to infect mefenoxam-treated tubers from the replicated small plot trials in 2008 and 2009 differed markedly (Table 2, Fig. 2). Significant

Table 2. Disease incidence among tubers of cultivar Russet Burbank grown in replicated small plot ( 0.003 ha per experimental unit) field trials in 2008 and 2009 that were challenge inoculated with mefenoxam-sensitive and -resistant isolates of Phytophthora erythroseptica

\begin{tabular}{|c|c|c|c|c|c|c|c|c|c|c|}
\hline \multirow[b]{3}{*}{ Isolate } & \multirow[b]{3}{*}{ Fungicide $^{\mathrm{x}}$} & \multirow{3}{*}{$\begin{array}{c}\text { Rate } \\
\left(\mathrm{g} \text { a.i. } \mathbf{h a}^{-1}\right)\end{array}$} & \multirow{3}{*}{$\begin{array}{c}\text { Application } \\
\text { timingy }^{y}\end{array}$} & \multicolumn{7}{|c|}{ Disease incidence $(\%)^{\mathrm{v}}$} \\
\hline & & & & \multicolumn{7}{|c|}{ Days after harvest ${ }^{w}$} \\
\hline & & & & 30 & 65 & 95 & 124 & 142 & 163 & 187 \\
\hline \multicolumn{11}{|c|}{ Mefenoxam-sensitive } \\
\hline & Nontreated & & & $22.5 \mathrm{a}$ & $16.3 \mathrm{a}$ & $38.8 \mathrm{a}$ & $17.5 \mathrm{a}$ & $16.3 \mathrm{a}$ & $23.8 \mathrm{a}$ & $32.5 \mathrm{a}$ \\
\hline & Mefenoxam & 213.5 & In-furrow & $5.0 \mathrm{bc}$ & $1.3 \mathrm{~cd}$ & $10.0 \mathrm{bc}$ & $7.5 \mathrm{bcd}$ & $0.0 \mathrm{c}$ & $6.3 \mathrm{bc}$ & $7.5 \mathrm{bcd}$ \\
\hline & Mefenoxam & 427.0 & In-furrow & $7.5 \mathrm{bc}$ & $10.0 \mathrm{abc}$ & $11.3 \mathrm{bc}$ & $8.8 \mathrm{bc}$ & $5.0 \mathrm{bc}$ & $11.3 \mathrm{~b}$ & $13.8 \mathrm{bc}$ \\
\hline & Mefenoxam & 213.5 & In-furrow & $1.3 \mathrm{c}$ & $5.0 \mathrm{bcd}$ & $10.0 \mathrm{bc}$ & $7.5 \mathrm{bcd}$ & $6.3 \mathrm{~b}$ & $3.8 \mathrm{bc}$ & $8.8 \mathrm{bcd}$ \\
\hline & Mefenoxam & 213.5 & Sidedress & & & & & & & \\
\hline & Mefenoxam & 213.5 & In-furrow & $2.5 \mathrm{c}$ & $11.3 \mathrm{ab}$ & $12.5 \mathrm{~b}$ & $10.0 \mathrm{~b}$ & $5.0 \mathrm{bc}$ & $11.3 \mathrm{~b}$ & $15.0 \mathrm{~b}$ \\
\hline & Mefenoxam & 89.7 & Tuber initiation & & & & & & & \\
\hline & Mefenoxam & 89.7 & 2 foliar & $1.3 \mathrm{c}$ & $13.8 \mathrm{ab}$ & $8.8 \mathrm{bcd}$ & $2.5 \mathrm{cde}$ & $1.3 \mathrm{bc}$ & $11.3 \mathrm{~b}$ & $11.3 \mathrm{bcd}$ \\
\hline & Phosphorous acid & 8,766 & Tuber initiation & $13.8 \mathrm{ab}$ & $15.0 \mathrm{a}$ & $13.8 \mathrm{~b}$ & 3.8 bcde & $1.3 \mathrm{bc}$ & $2.5 \mathrm{bc}$ & $8.8 \mathrm{bcd}$ \\
\hline & Phosphorous acid & 8,766 & 2 foliar & $3.8 \mathrm{c}$ & $1.3 \mathrm{~cd}$ & $2.5 \mathrm{~cd}$ & $1.3 \mathrm{de}$ & $2.5 \mathrm{bc}$ & $2.5 \mathrm{bc}$ & $3.8 \mathrm{~cd}$ \\
\hline & Phosphorous acid & 8,766 & 3 foliar & $1.3 \mathrm{c}$ & $1.3 \mathrm{~cd}$ & $0.0 \mathrm{~d}$ & $1.3 \mathrm{de}$ & $0.0 \mathrm{c}$ & $0.0 \mathrm{c}$ & $1.3 \mathrm{~d}$ \\
\hline & Phosphorous acid & $284^{\mathrm{z}}$ & Postharvest & $0.0 \mathrm{c}$ & $0.0 \mathrm{~d}$ & $0.0 \mathrm{~d}$ & $0.0 \mathrm{e}$ & $0.0 \mathrm{c}$ & $0.0 \mathrm{c}$ & $2.5 \mathrm{~d}$ \\
\hline & $P$ value & & & $<0.0001$ & 0.0002 & $<0.0001$ & $<0.0001$ & $<0.0001$ & 0.0009 & $<0.0001$ \\
\hline \multicolumn{11}{|c|}{ Mefenoxam-resistant } \\
\hline & Nontreated & & & $35.0 \mathrm{a}$ & $23.8 \mathrm{ab}$ & $26.3 \mathrm{ab}$ & $25.0 \mathrm{ab}$ & $21.3 \mathrm{a}$ & $16.3 \mathrm{ab}$ & $36.3 \mathrm{ab}$ \\
\hline & Mefenoxam & 213.5 & In-furrow & $25.0 \mathrm{ab}$ & $20.0 \mathrm{ab}$ & $33.8 \mathrm{a}$ & $23.8 \mathrm{ab}$ & $18.8 \mathrm{a}$ & $17.5 \mathrm{ab}$ & $36.3 \mathrm{ab}$ \\
\hline & Mefenoxam & 427.0 & In-furrow & $36.3 \mathrm{a}$ & $25.0 \mathrm{ab}$ & $31.3 \mathrm{a}$ & $26.3 \mathrm{a}$ & $13.8 \mathrm{ab}$ & $15.0 \mathrm{ab}$ & $30.0 \mathrm{bc}$ \\
\hline & Mefenoxam & 213.5 & In-furrow & $31.3 \mathrm{ab}$ & $23.8 \mathrm{ab}$ & $33.8 \mathrm{a}$ & $17.5 \mathrm{abc}$ & $15.0 \mathrm{ab}$ & $23.8 \mathrm{ab}$ & $43.8 \mathrm{ab}$ \\
\hline & Mefenoxam & 213.5 & Sidedress & & & & & & & \\
\hline & Mefenoxam & 213.5 & In-furrow & $31.3 \mathrm{ab}$ & $28.8 \mathrm{a}$ & $35.0 \mathrm{a}$ & $15.0 \mathrm{abc}$ & $18.8 \mathrm{a}$ & $17.5 \mathrm{ab}$ & $47.5 \mathrm{a}$ \\
\hline & Mefenoxam & 89.7 & Tuber initiation & & & & & & & \\
\hline & Mefenoxam & 89.7 & 2 foliar & $37.5 \mathrm{a}$ & $20.0 \mathrm{ab}$ & $25.0 \mathrm{ab}$ & $11.3 \mathrm{bcd}$ & $15.0 \mathrm{ab}$ & $26.3 \mathrm{a}$ & $30.0 \mathrm{bc}$ \\
\hline & Phosphorous acid & 8,766 & Tuber initiation & $21.3 \mathrm{bc}$ & $16.3 \mathrm{~b}$ & $15.0 \mathrm{bc}$ & $6.3 \mathrm{~cd}$ & $7.5 \mathrm{bc}$ & $10.0 \mathrm{bc}$ & $16.3 \mathrm{~cd}$ \\
\hline & Phosphorous acid & 8,766 & 2 foliar & $8.8 \mathrm{~cd}$ & $1.3 \mathrm{c}$ & $5.0 \mathrm{c}$ & $0.0 \mathrm{~d}$ & $0.0 \mathrm{c}$ & $0.0 \mathrm{c}$ & $5.0 \mathrm{~d}$ \\
\hline & Phosphorous acid & 8,766 & 3 foliar & $2.5 \mathrm{~d}$ & $2.5 \mathrm{c}$ & $8.8 \mathrm{c}$ & $0.0 \mathrm{~d}$ & $0.0 \mathrm{c}$ & $0.0 \mathrm{c}$ & $6.3 \mathrm{~d}$ \\
\hline & Phosphorous acid & $284^{\mathrm{z}}$ & Postharvest & $0.0 \mathrm{~d}$ & $0.0 \mathrm{c}$ & $0.0 \mathrm{c}$ & $0.0 \mathrm{~d}$ & $0.0 \mathrm{c}$ & $0.0 \mathrm{c}$ & $0.0 \mathrm{~d}$ \\
\hline & $P$ value & & & $<0.0001$ & $<0.0001$ & $<0.0001$ & $<0.0001$ & $<0.0001$ & 0.0005 & $<0.0001$ \\
\hline
\end{tabular}

${ }^{\mathrm{v}}$ Disease incidences within a column followed by the same letter were not significantly different according to Fisher's protected least significant difference test $(\alpha=0.05)$. Analyses were conducted within mefenoxam-sensitive or -resistant isolates.

${ }^{\text {w }}$ Mean days after harvest that tuber challenge inoculations took place in 2008 and 2009. Actual time periods between inoculation dates differed by 1 to 8 days.

x Phosphorous acid applied as Phostrol, mefenoxam applied as Ridomil Gold 4EC or Ridomil Gold MZ.

y Foliar applications were made at tuber-initiation, as well as 14 days ( 2 foliar) and 28 days ( 3 foliar) post-tuber initiation where applicable.

${ }^{\mathrm{z}} \mathrm{g}$ a.i. metric ton $^{-1}$.

Table 3. $F$ statistic and $P$ value from the two-way factorial analysis of variance performed with Phytophthora erythroseptica isolate sensitivity to mefenoxam (Isolate) and fungicide treatment (Treatment) as main effects

\begin{tabular}{|c|c|c|c|c|c|c|c|c|c|c|c|c|c|c|}
\hline \multirow[b]{3}{*}{ Factor } & \multicolumn{14}{|c|}{ Days after harvest ${ }^{\mathrm{z}}$} \\
\hline & \multicolumn{2}{|c|}{30} & \multicolumn{2}{|c|}{65} & \multicolumn{2}{|c|}{95} & \multicolumn{2}{|c|}{124} & \multicolumn{2}{|c|}{142} & \multicolumn{2}{|c|}{163} & \multicolumn{2}{|c|}{187} \\
\hline & $\boldsymbol{F}$ & $P$ & $F$ & $P$ & $F$ & $P$ & $F$ & $P$ & $\boldsymbol{F}$ & $\boldsymbol{P}$ & $\boldsymbol{F}$ & $P$ & $\boldsymbol{F}$ & $P$ \\
\hline Treatment & 10.31 & $<0.0001$ & 8.74 & $<0.0001$ & 11.12 & $<0.0001$ & 7.45 & $<0.0001$ & 10.86 & $<0.0001$ & 5.94 & $<0.0001$ & 10.55 & $<0.0001$ \\
\hline Isolate & 91.03 & $<0.0001$ & 25.93 & $<0.0001$ & 29.02 & $<0.0001$ & 13.31 & 0.0004 & 39.63 & $<0.0001$ & 7.52 & 0.0069 & 40.67 & $<0.0001$ \\
\hline $\begin{array}{l}\text { Isolate } \times \\
\text { Treatment }\end{array}$ & 5.66 & $<0.0001$ & 2.28 & 0.0205 & 4.03 & 0.0001 & 1.45 & 0.1718 & 3.58 & 0.0005 & 1.84 & 0.0671 & 3.57 & 0.0005 \\
\hline
\end{tabular}

${ }^{\mathrm{z}}$ Mean days after harvest challenge inoculations took place in 2008 and 2009. Actual time periods between inoculation dates differed by 1 to 8 days. 
differences in disease incidence were not observed between the nontreated control and any mefenoxam-based fungicide treatment in tubers inoculated with the mefenoxam-resistant isolate. However, with few exceptions, mefenoxam significantly reduced disease incidence with the mefenoxam-sensitive isolate. In contrast, foliar applications of phosphorous acid significantly reduced the level of infection of both isolates in most instances when compared to the nontreated control and mefenoxam treatments. A single foliar application of phosphorous acid significantly reduced disease incidence obtained with the mefenoxam resistant isolate, but was not always significantly better than the nontreated control over the course of the study. Significant reductions in tuber infections caused by the mefenoxam-sensitive isolate were evident from 95 days through 185 days postharvest, but reductions in tuber infection incited by the mefenoxam-resistant isolate were not significant. Disease incidence of both isolates was consistently reduced with two and three foliar and with postharvest applications of phosphorous acid, resulting in significant differences from the nontreated control with both isolates at all dates. The magnitude of these reductions varied with isolate and time after harvest when the tubers were inoculated.

As with disease incidence, disease control variances were homogeneous across all inoculation dates, and therefore data were combined. Additionally, the main effects of mefenoxam sensitivity of the $P$. erythroseptica isolate $(P<0.0001)$ and fungicide treatment $(P<0.0001)$ were significant, as was the interaction between these two main effects $(P<0.0001)$. All mefenoxam treatments were effective against the mefenoxam-sensitive isolate following challenge inoculations, with levels of disease control ranging from 55 to $76 \%(P<0.0001)$ (Fig. 2A). Phosphorous acid also was highly effective in controlling the mefenoxam-sensitive isolate. A single foliar application reduced pink rot incidence by $54 \%$, and two and
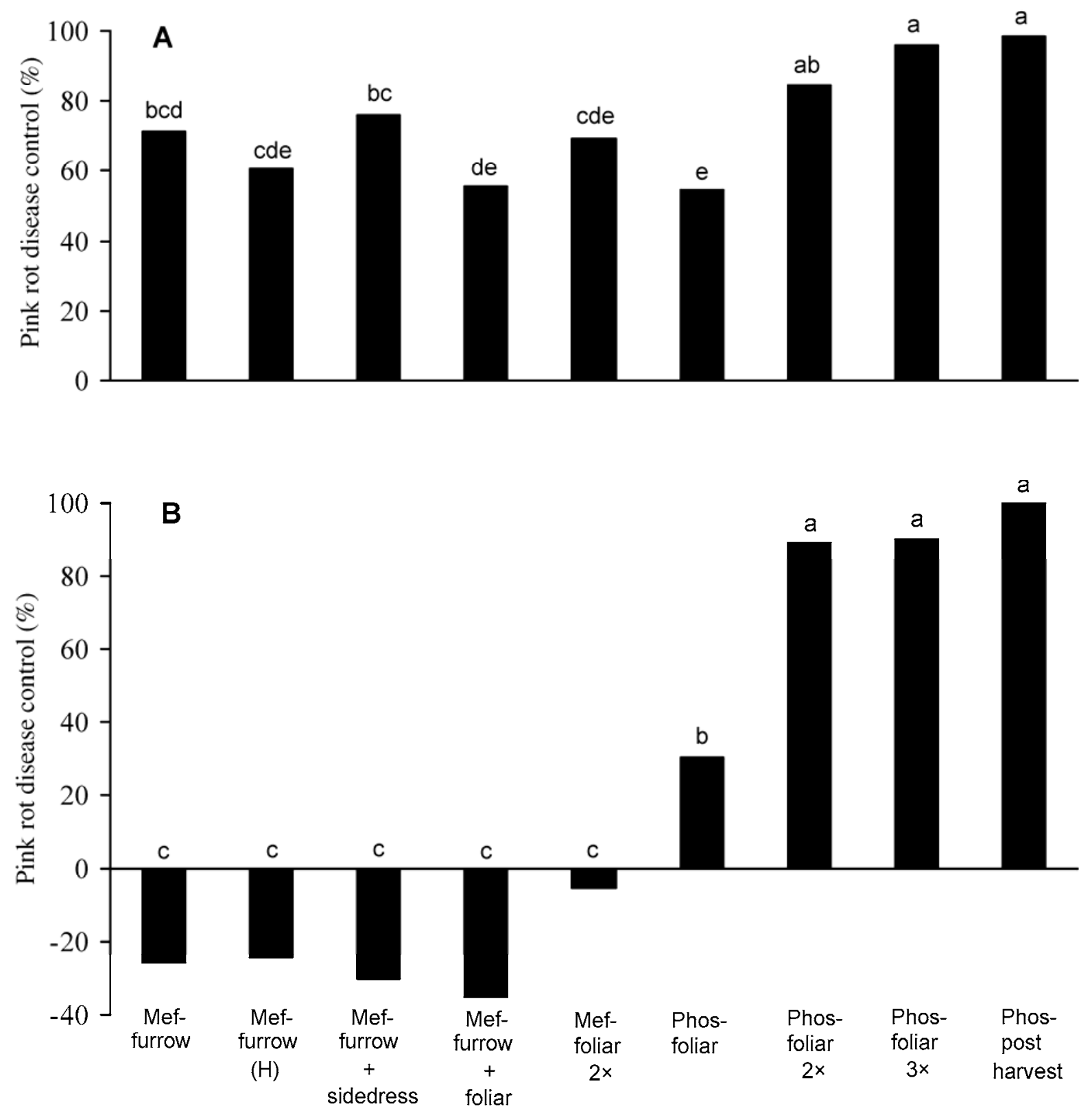

Fig. 2. Percent disease control of pink rot infection in potato tubers challenge-inoculated with a mefenoxam-sensitive (A) and -resistant (B) isolate of Phytophthora erythroseptica in replicated small plot trials performed in 2008 and 2009. Tubers were grown from plants treated with mefenoxam in-furrow (Mef-furrow) and at sidedress at a rate of $213.5 \mathrm{~g}$ a.i. ha- ${ }^{-1}$ unless noted as a high rate $(\mathrm{H})$ of $427 \mathrm{~g}$ a.i. ha- ${ }^{-1}$. Mefenoxam (Mef-foliar $2 \mathrm{x}$ ) or phosphorous acid (Phos-foliar 2x) were applied to the foliage at tuber initiation and 14 days post-tuber initiation at a rate of $89.7 \mathrm{~g}$ a.i. ha-1 or $8,766 \mathrm{~g}$ a.i. ha ${ }^{-1}$, respectively. Phosphorous acid also was applied to the foliage at tuber initiation, 14 and 28 days post-tuber initiation (Phos-foliar $3 \times$ ) at a rate of $8,766 \mathrm{~g}$ a.i. ha- ${ }^{-1}$ and to tubers 10 days postharvest (Phos-post harvest) at a rate of $284 \mathrm{~g}$ a.i. metric ton ${ }^{-1}$. All infurrow, sidedress, and foliar treatments were applied with a water volume of 75,187 , and 187 liters ha- ${ }^{-1}$, respectively. Postharvest applications were made with 2.1 liters metric ton ${ }^{-1}$ of water. Treatment means with the same letter are not significantly different according to Fisher's protected least significant difference test $(\alpha=0.05)$. 
three foliar applications resulted in significantly greater control at 84 and $96 \%$, respectively. One and two applications of phosphorous acid were as effective in controlling the mefenoxam-sensitive isolate as any mefenoxam treatment, and three applications provided significantly greater control relative to all mefenoxam applications. Mefenoxam not only failed to control the mefenoxam-resistant isolate regardless of the application rate or timing, but also caused an increase in disease incidence resulting in negative percentages of disease control $(P<0.0001)$ (Fig. 2B). In contrast, all phosphorous acid treatments provided significant levels of control of the mefenoxam-resistant isolate (Fig. 2B). A single foliar application of phosphorous acid decreased pink rot incidence by $30 \%$, and significantly greater control $(90 \%)$ was achieved with two and three applications. Postharvest treatments of potato tubers with phosphorous acid nearly completely controlled both mefenoxam-sensitive and -resistant $P$. erythroseptica isolates throughout the duration of the 6-month storage period (Fig. 2).

Chemigation versus aerial application of phosphorous acid. Variances were homogeneous among replicated split commercial field trials conducted in 2008 and 2009 to compare aerial versus chemigation and two versus three aerial applications. Therefore, data were combined for further analysis where appropriate. In replicated split commercial field trials, phosphorous acid applied either aerially or via chemigation significantly reduced pink rot incidence compared to nontreated control tubers in postharvest challenge inoculation studies conducted with a mefenoxam-sensitive strain of $P$. erythroseptica (Fig. 3). Pink rot disease incidence observed in 2008 and 2009 with two and three aerial applications of phosphorous acid fungicide were significantly lower when compared to the nontreated control $(P<0.0001 ; P=0.0005)$. However, there were no significant differences in pink rot disease incidence between treatments involving two and three applications of the fungicide applied by fixed-wing aircraft (Fig. 3A and B). Interestingly, three chemigation applications of phosphorous acid significantly reduced pink rot incidence in 2008 but not in 2009 compared to the nontreated control (Fig. 3C and D). In contrast, three aerial applications of phosphorous acid were significantly better than the nontreated control in both 2008 and $2009(P<0.0001 ; P=$ 0.0023 ). Additionally, three aerial applications of phosphorous acid provided the same level of pink rot control as three chemigation applications in 2008 , but were significantly more effective than the chemigation applications in 2009.
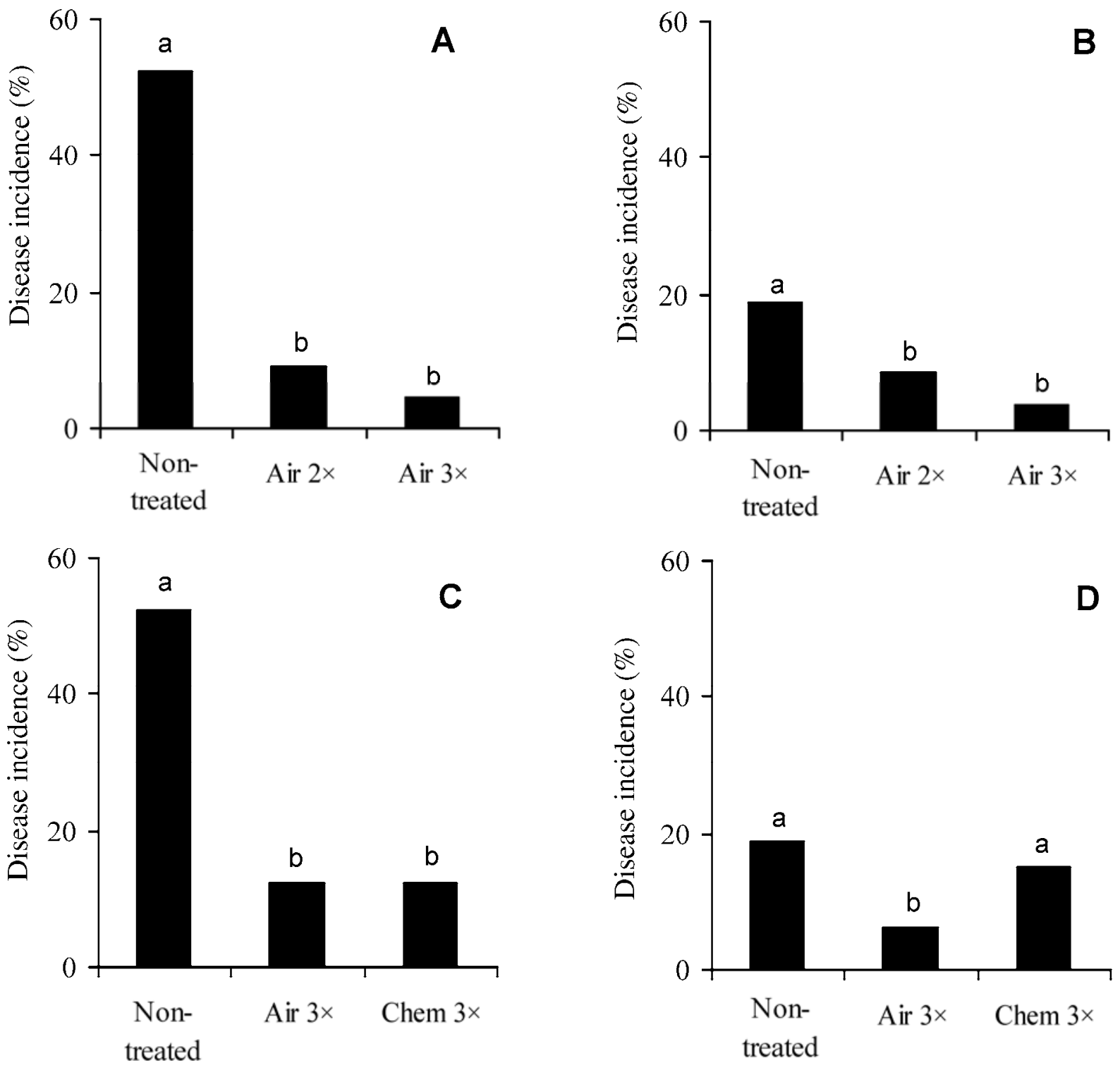

Fig. 3. Disease incidence of potato tubers cv. Russet Burbank challenge inoculated with a mefenoxam-sensitive isolate of Phytophthora erythroseptica. Tubers were obtained from replicated split commercial fields in Minnesota in $2008(A, C)$ and $2009(B, D)$ to compare application frequency $(A, B)$ and method $(C, D)$ of phosphorous acid fungicide for the control of pink rot. Two (2x) and three (3x) applications were performed at tuber initiation, 14 and 28 days later as applicable at a rate of $8,766 \mathrm{~g}$ a.i. ha ${ }^{-1}$. Phosphorous acid was applied by a fixed-wing aircraft (Air) with a water volume of 47 liters ha-1 or via the irrigation system (Chem.) with a water volume of 25,700 to 63,460 liters ha ${ }^{-1}$. Treatment means with the same letter are not significantly different according to Fisher's protected least significant difference test $(\alpha=0.05)$. 


\section{Discussion}

Pink rot has become an increasingly important problem for the potato industry since the mid-1990s, in part due to the development of mefenoxam-resistance in $P$. erythroseptica populations during that time (52). Mefenoxam resistance in P. erythroseptica is very prevalent in Minnesota where the studies reported here were conducted (9). Prior to this, mefenoxam (metalaxyl) had been the only fungicide successfully used to manage pink rot in potato $(31,32,42,46,53,56)$ and remains an effective tool for controlling $P$. erythroseptica in populations sensitive to the fungicide $(20,49,51)$ such as in North Dakota (9). Results of the current studies again confirm this. In-furrow applications of mefenoxam significantly reduced the level of pink rot in the field when a mefenoxam-sensitive isolate provided the disease pressure. Pink rot incidence was reduced by approximately 60 to $75 \%$ following in-furrow applications of mefenoxam in all experiments conducted in 2006, 2007, 2008, and 2009, and these levels of control are similar to those reported previously for this application method $(49,51)$. Mefenoxam also provided significant levels of control of the mefenoxam-sensitive isolate through 187 days in storage. These results also are consistent with observations made in previous studies which demonstrated residual biological activity in tubers in storage for up to 6 months $(2,7,41)$. Data reported here demonstrate that residual control of pink rot with mefenoxam is not rate responsive in a moderately susceptible potato cultivar such as Russet Burbank (44). Similar levels of pink rot control in storage provided by both low and high rates of in-furrow applications of mefenoxam indicate an economical advantage in applying mefenoxam at the lower rate in fields containing sensitive pathogen populations. However, neither level of mefenoxam protected tubers from infection by the mefenoxam-resistant isolate of $P$. erythroseptica. In fact, negative disease control of the mefenoxam-resistant isolate in mefenoxam treated tubers noted here represents a level of enhanced aggressiveness in the presence of mefenoxam which has been observed previously (49).

Earlier work documented significant reductions in disease incidence following two and three foliar applications of phosphorous acid under severe inoculum pressure (24). In that study, incidences of 84 to $100 \%$ were recorded in controls from most test locations. Disease pressures this high can occur in localized foci in potato fields, and it is noteworthy that this study still was able to quantify significant levels of control under these conditions. Lower levels of pink rot were observed in the controls in the present study, generally falling in the range of 20 to $50 \%$ over all experiments. Significant reductions in pink rot were observed in tubers from plants treated with two and three applications of phosphorous acid, supporting previously reported findings (24), but significant levels of disease control also were observed following one application of phosphorous acid under these conditions. Pink rot control with a single foliar application of phosphorous acid had not been reported prior to the current study. These results demonstrate the effectiveness of single and multiple applications of phosphorous acid in controlling pink rot and that this fungicide can provide levels of protection similar to those afforded by in-furrow applications of mefenoxam.

It previously has been noted that phosphorous acid could provide residual control of pink rot up to 30 days following harvest $(23,24,29)$, but these studies did not did not evaluate the fungicide's efficacy during longer storage periods. The results of the work discussed here support those observations and provide additional information regarding the effectiveness of phosphorous acid applications, demonstrating efficacy for an extended period of nearly 200 days of storage, far beyond the duration previously determined. Although three foliar applications of phosphorous acid significantly controlled pink rot, the current results also demonstrate the economic benefit of using one or two foliar applications of phosphorous acid to control the disease caused by either mefenoxam-sensitive or -resistant strains of $P$. erythroseptica. Postharvest applications of phosphorous acid were particularly impres- sive in the level of pink rot disease control obtained in the current studies. Of the 1,120 tubers treated with phosphorous acid postharvest over the 2 years of this study, infections were recorded in only two tubers following challenge inoculations with either a mefenoxam-sensitive or -resistant isolate.

While postharvest applications may provide nearly complete control of pink rot infections that occur during harvest operations (45), postharvest applications of phosphorous acid will have no impact on infections occurring in the field prior to harvest. Therefore, foliar applications may be more advantageous than postharvest applications. Furthermore, past work demonstrating the efficacy of phosphorous acid in controlling pink rot has been restricted to postharvest inoculation challenges $(23,24,29)$. The current study represents the first direct documentation of foliar applications of phosphorous acid controlling the level of pink rot in the field. Significant reductions in tuber rot were observed in these trials. The extent of these reductions probably is underestimated, as many tubers from the nontreated controls completely decayed in the ground and were not harvestable. These results corroborate results obtained in challenge inoculation work reported here and observations made in earlier studies.

The results of replicated split commercial field trials validated the results obtained in replicated small plot trials. Two applications of phosphorous acid proved to be as efficacious as three applications of the fungicide in both types of trials. This is valuable information for potato producers since phosphorous acid is a more expensive fungicide alternative than mefenoxam-based fungicides for the control of pink rot, especially considering that phosphorous acid does not control leak tuber rot (24), which is suppressed by mefenoxam (51). It also is important to note that the cultivar used throughout these studies was Russet Burbank, which is moderately susceptible to pink rot (44). While two applications of phosphorous acid may be sufficient to provide excellent control of pink rot in this cultivar, additional applications of phosphorous acid may be needed to control the disease in a more susceptible cultivar as previously demonstrated using mefenoxam-based fungicides (50).

The volume of water used to apply phosphorous acid fungicides is another concern of potato producers, largely because the applications of this fungicide with fixed-wing aircraft using water volumes of 47 liters $\mathrm{ha}^{-1}$, commonly used in the potato industry, frequently causes burning of foliage under Midwest potato production conditions (unpublished). Foliar fungicides in the above-mentioned replicated small plot field studies were applied using a small ground sprayer and water volumes of 560 liters ha ${ }^{-1}$. However, aerial sprays and chemigation are the two most widely used methods of applying fungicide to the potato crop in a commercial setting using water volumes of 47 and $>25,000$ liters $\mathrm{ha}^{-1}$, respectively. The results of postharvest challenge inoculations of tubers collected from large-scale replicated split commercial field trials demonstrate that phosphorous acid will provide pink rot control via either application method, but aerial applications appear to be more effective. With chemigation applications, a large proportion of a fungicide delivered to the crop will pass through the canopy and accumulate in the soil for absorption by the roots. Although phosphorous acid can be taken up by the roots and quickly concentrate in stem and leaf tissue in some crop species (11), it apparently either is not absorbed through the roots in potato, or not translocated efficiently. In a recent 2 -year study, in-furrow applications at recommended label rates did not provide effective pink rot control (1), agreeing with the results reported here. Although slight reductions in pink rot incidence were noted with in-furrow applications in that study, the extent of these reductions was not statistically significant. The authors speculated that this may be due to direct suppression of the pathogen in the soil prior to infection. These results are interesting and may deserve further investigation to examine factors that influence phosphorous acid fungicidal activity in the soil and uptake by the potato root system. Regardless, in the studies reported here, pink rot control was variable when phosphorous acid was applied via chemigation. Further studies on chemigation of phosphorous acid should be conducted to improve and pro- 
vide more consistent control of pink rot using this application method. Chemigation is attractive to potato growers because, as opposed to foliar applications with fixed-wing aircraft, burning of the foliage has not been observed when phosphorous acid is applied with these high water volumes.

The longevity of biological activity of mefenoxam in tuber tissue has been documented $(2,7,41)$; however, extended residual bioactivity of phosphonates had not been studied prior to the current work. Experiments designed to simulate wounding during harvest and handling (23) demonstrated control of pink rot when tubers were treated with phosphorous acid following wounding and inoculation. Wounding can affect pink rot incidence $(35,45)$, and since metalaxyl is concentrated in or near the periderm (7), the efficacy of that fungicide is reduced markedly if this protective barrier is breached (51). Since the pathogen easily can be spread from damaged, rotted tubers to healthy tubers during harvest and handling operations, any infected tissue adhering to healthy tubers serves as inoculum. Therefore, it is essential that a fungicide limit new infections while tubers are in storage. Results reported here demonstrate that phosphorous acid will provide protection for an extended storage period and generally provide a greater level of disease control than mefenoxam.

Although mefenoxam controls pink rot in many situations, phosphorous acid offers distinct advantages as an alternative fungicide. In addition to the systemic nature of its mobility, being translocated both acropetally and basipetally (11), and its relative longevity within the plant $(34,47)$, phosphorous acid possesses many other characteristics that make it ideally suited as a disease control agent. Phosphorous acid has a complex mode of action $(18,22,47)$ involving several biochemical processes, and this greatly reduces the likelihood that resistance will appear in the pathogen population. Resistance to phosphonate fungicides has been induced in $P$. capsici under laboratory conditions $(5,18)$ but has been documented in the field only rarely, being linked to long-term use against Bremia lactucae on lettuce (6) and P. cinnamomi on avocado (14) and cypress (54). Growers should remain vigilant and be aware that although the likelihood of resistance developing to phosphorous acid is low, the potential still exists. In light of these observations and the results discussed here, a successful pink rot management program should incorporate the use of both mefenoxam and phosphonate fungicides, either alternated or in combination, to limit the probability of resistance emerging and to preserve the efficacy of both fungicides. To maximize efficacy of the fungicide and minimize costs associated with its application, two foliar applications via aerial spray and/or a single postharvest treatment should control pink rot regardless of the mefenoxam sensitivity of the native population of $P$. erythroseptica.

In addition to its potential impact upon the development of resistance and control of mefenoxam-resistant strains of $P$. erythroseptica, phosphorous acid may have other benefits. The fungicide is not toxic to nontarget organisms and therefore does not adversely affect the environment. Phosphorous acid also has been associated with increased lipid content of roots and stimulation of sugar exudation by roots (11). Little is known about the effect such increased levels of sugar or other induced compounds would have on the microorganisms in the rhizosphere. Isolates that demonstrate antibiosis against $P$. erythroseptica have been collected from both exoroot and endoroot microbial communities (48). Shifts in these populations could have a profound influence upon $P$. erythroseptica and pink rot development $(37,38)$. It is possible that these rhizomicrobial communities could be affected either positively or negatively by root exudates. Because phosphonate fungicides have a complex mode of action, their effects upon plant metabolism, especially potato tuber and root physiology, is another area of research that deserves more attention. The effects phosphorus acid compounds have on potato physiology and conditions required to maximize their efficacy in controlling pink rot should be assessed. It previously had been suggested that studies evaluating the efficacy of phosphorous acid application methods were needed (1). The results reported here, particularly those obtained in replicated split field trials under commercial production conditions, provide some of these details, but additional research is warranted.

\section{Acknowledgments}

We thank Dean Peterson, Russell Benz, and Roberta Sherman for technical assistance. We also acknowledge the financial support of the MN Area II Potato Growers Association and R.D. Offutt Farms for their cooperation in establishing replicated split commercial field trials to evaluate phosphorous acid efficacy.

\section{Literature Cited}

1. Al-Mughrabi, K. I., Peters R. D., Platt, H. W. (Bud), Moreau, G., Vikram, A., Poirier, R., and MacDonald, I. 2007. In-furrow applications of metalaxyl and phosphite for control of pink rot (Phytophthora erythroseptica) of potato in New Brunswick, Canada. Plant Dis. 91:1305-1309.

2. Barak, E., Edgington, L. V., and Ripley, B. D. 1984. Bioactivity of the fungicide metalaxyl in potato tubers against some species of Phytophthora Fusarium, and Alternaria, related to polyphenoloxidase activity. Can. J. Plant Pathol. 6:304-308.

3. Blodgett, E. C. 1945. Water rot of potatoes. Plant Dis. Rep. 29:124-126.

4. Bonde, R. 1938. The occurrence of pink-rot and wilt in Maine. Plant Dis. Rep. 22:460.

5. Bower, L. A., and Coffey, M. D. 1985. Development of laboratory tolerance to phosphorous acid, fosetyl-Al, and metalaxyl in Phytophthora capsici. Can. J. Plant Pathol. 7:1-6.

6. Brown, S., Koike, S. T., Ochoa, O. E., Laemmlen, F., and Michelmore, R. W. 2004. Insensitivity to the fungicide fosetyl-aluminum in California isolates of the lettuce downy mildew pathogen, Bremia lactucae. Plant Dis. 88:502-508.

7. Bruin, G. C. A., Edgington, L. V., and Ripley, B. D. 1982. Bioactivity of the fungicide metalaxyl in potato tubers after foliar sprays. Can. J. Plant Pathol 4:353-356.

8. Cairns, H., and Muskett, A. E. 1933. Pink rot of the potato. Ann. Appl. Biol. 20:381-403.

9. Chapara, V., Taylor, R. J., Pasche, J. S., and Gudmestad, N. C. 2010. Prevalence of mefenoxam resistance among Phytophthora erythroseptica Pethybridge isolates in Minnesota and North Dakota. Am. J. Potato Res. 87:521530 .

10. Coffey, M. D., and Bower, L. A. 1984. In vitro variability among isolates of eight Phytophthora species in response to phosphorous acid. Phytopathology 74:738-742.

11. Cohen, Y., and Coffey, M. D. 1986. Systemic fungicides and the control of oomycetes. Annu. Rev. Phytopathol. 24:311-338.

12. Cooke, L. R., and Little, G. 2001. The effect of foliar application of phosphonate formulations on the susceptibility of potato tubers to late blight Pest Manag. Sci. 58:17-25.

13. Cunliffe, C., Lonsdale, D., and Epton, H. A. S. 1977. Transmission of Phytophthora erythroseptica on stored potatoes. Trans. Br. Mycol. Soc. 69:2730 .

14. Dobrowolski, M. P., Shearer, B. L., Colquhoun, I. J., O’Brien, P. A., and Hardy, G. E. StJ. 2008. Selection for decreased sensitivity to phosphite in Phytophthora cinnamomi with prolonged use of fungicide. Plant Pathol. 57:928-936.

15. Dunstan, R. H., Smillie, R. H., and Guest, B. R. 1990. The effects of subtoxic levels of phosphonate on the metabolism and potential virulence factors of Phytoththora palmivora. Physiol. Mol. Plant Pathol. 36:205-220.

16. Erwin, D. C., and Ribeiro, O. K. 1996. Phytophthora Diseases Worldwide. American Phytopathological Society, St. Paul, MN.

17. Fenn, M. E., and Coffey, M. D. 1984. Studies on the in vitro and in vivo antifungal activity of fosetyl-Al and phosphorous acid. Phytopathology 74:606-611.

18. Fenn, M. E., and Coffey, M. D. 1985. Further evidence for the direct mode of action of fosetyl-Al and phosphorous acid. Phytopathology 75:10641068 .

19. Fenn, M. E., and Coffey, M. D. 1989. Quantification of phosphonate and ethyl phosphonate in tobacco and tomato tissues and significance for the mode of action of two phosphonate fungicides. Phytopathology 79:76-82.

20. Gudmestad, N. C., Taylor, R. A., and Pasche, J. S. 2007. Management of soilborne diseases of potato. Australas. Plant Pathol. 36:109-115.

21. Guest, D. I. 1984. Modification of defense responses in tobacco and capsicum following treatment with fosetyl-Al [aluminum tris(o-ethyl phosphonate)]. Physiol. Plant Pathol. 25:125-134.

22. Guest, D. I., and Bompeix, G. 1990. The complex mode of action of phosphonates. Australas. Plant Pathol. 19:113-115.

23. Johnson, S. B. 2008. Post-harvest applications of phosphorous acid materials for control of Phytophthora infestans and Phytophthora erythroseptica on potatoes. Plant Pathol. J. 7:50-53.

24. Johnson, D. A., Inglis, D. A., and Miller, J. S. 2004. Control of potato tuber rots caused by oomycetes with foliar applications of phosphorous acid. Plant Dis. 88:1153-1159.

25. Lambert, D. H., and Salas, B. 2001. Pink rot. Pages 33-34 in: Compendium of Potato Diseases, 2nd ed. W. R. Stevenson, R. Loria, G. D. Franc, and D. P. Weingartner, eds. American Phytopathological Society, St. Paul, MN.

26. Lennard, J. H. 1980. Factors influencing the development of potato pink rot 
(Phytophthora erythroseptica). Plant Pathol. 29:80-86.

27. Lonsdale, D., Cunliffe, C., and Epton, H. A. S. 1980. Possible routes of entry of Phytophthora erythroseptica Pethyb. and its growth within potato plants. Phytopathol. Z. 97:109-117.

28. Mayton, H., Myers, K., and Fry, W. E. 2008. Potato late blight in tubers The role of foliar phosphonate applications in suppressing pre-harvest tuber infections. Crop Prot. 27:943-950.

29. Miller, J. S., Olson, N., Woodell, L., Porter, L. D., and Clayson, S. 2006. Post-harvest applications of zoxamide and phosphite for control of potato tuber rots caused by oomycetes at harvest. Am. J. Potato Res. 83:269-273.

30. Millikin, G. A., and Johnson, D. E. 1992. One-way treatment structure in a completely randomized design with heterogeneious errors. Pages 16-28 in: Analysis of Messy Data. Vol. 1. Designed Experiments. Chapman and Hall, London, UK.

31. Mulrooney, R. P., and Gregory, N. F. 2001. Evaluation of foliar and soil applied fungicides for the control of pink rot of potato, 2000. Fungic. Nematicide Tests 56:49.

32. Mulrooney, R. P., and Gregory, N. F. 2002. Evaluation of foliar and soil applied fungicides for the control of pink rot of potato, 2001. Fungic. Nematicide Tests 57:66.

33. Ouimette, D. G., and Coffey, M. D. 1989. Comparative antifungal activity of four phosphonate compounds against isolates of nine Phytophthora species. Phytopathology 79:761-767.

34. Ouimette, D. G., and Coffey, M. D. 1989. Phosphonate levels in avocado (Persea americana) seedlings and soil following treatment with fosetyl-Al or potassium phosphonate. Plant Dis. 73:212-215.

35. Peters, R. D., and Sturz, A. V. 2001. A rapid technique for the evaluation of potato germ plasm for susceptibility to pink rot. Plant Dis. 85:833-837.

36. Peters, R. D., Sturz, A. V., and Arsenault, W. J. 2003. Use of mefenoxam to control pink rot (Phytophthora erythroseptica) of potato in Prince Edward Island. Can. J. Plant Pathol. 25:33-40.

37. Peters, R. D., Sturz, A. V., Carter, M. R., and Sanderson, J. B. 2003. Developing disease-suppressive soils through crop rotation and tillage management practices. Soil Tillage Res. 72:181-192.

38. Peters, R. D., Sturz, A. V., Carter, M. R., and Sanderson, J. B. 2005. Crop rotation can confirm resistance to potatoes from Phytophthora erythroseptica attack. Can. J. Plant Sci. 85:523-528.

39. Pethybridge, G.-H. 1913. On the rotting of potato tubers by a new species of Phytophthora having a method of sexual reproduction hitherto undescribed. Sci. Proc. Roy. Dublin Soc. 13:529-565.

40. Pethybridge, G.-H. 1914. Further observations on Phytophthora erythroseptica Pethyb. and on disease produced by it in the potato plant. Sci. Proc. Roy. Dublin Soc. 14:179-198.

41. Platt, B. 1994. Foliar application of fungicides affects occurrence of potato tuber rots caused by four foliar pathogens. Can. J. Plant Pathol. 16:341-346.

42. Powelson, M. L., Johnson, K. B., and Rowe, R. C. 1993. Management of diseases caused by soilborne pathogens. Pages 149-158 in: Potato Health Management. R. C. Rowe, ed. American Phytopathological Society, St. Paul, MN.

43. Saindrenan, P., Barchietto, T., Aveleno, J., and Bompeix, G. 1988. Effects of phosphate on phytoalexin accumulation in leaves of cowpea infected with Phytophthora cryptogea. Physiol. Mol. Plant Pathol. 32:425-435.

44. Salas, B., Secor, G. A., Taylor, R. J., and Gudmestad, N. C. 2003. Assessment of resistance of tubers of potato cultivars to Phythophthora erythroseptica and Pythium ultimum. Plant Dis. 87:91-97.

45. Salas, B., Stack, R. W., Secor, G. A., and Gudmestad, N. C. 2000. Effect of temperature, wounding, and inoculum density on the development of pink rot caused by Phytophthora erythroseptica. Plant Dis. 84:1327-1333.

46. Secor, G. A., and Gudmestad, N. C. 1999. Managing fungal diseases of potato. Can. J. Plant Pathol. 21:213-221.

47. Smillie, R. H., Grant, B. R., and Guest, D. I. 1989. The mode of action of phosphate: Evidence for both direct and indirect modes of action on three species of Phytophthora in plants. Phytopathology 79:921-926.

48. Sturz, A. V., Peters, R. D., Carter, M. R., Sanderson, J. B., Matheson, B. G., and Christie, B. R. 2005. Variation in antibiosis ability, against potato pathogens, of bacterial communities recovered from the endo- and exoroots of potato crops produced under conventional versus minimum tillage systems. Can. J. Microbiol. 51:643-654

49. Taylor, R. J., Pasche, J. S., and Gudmestad, N. C. 2006. Biological significance of mefenoxam resistance in Phytophthora erythroseptica and its implications for the management of pink rot of potato. Plant Dis. 90:927 934.

50. Taylor, R. J., Pasche, J. S., and Gudmestad, N. C. 2008. Susceptibility of eight potato cultivars to tuber infection by Phytophthora erythroseptica and Pythium ultimum and its relationship to mefenoxam-mediated control of pink rot and leak. Ann. Appl. Biol. 152:189-199.

51. Taylor, R. J., Salas, B., and Gudmestad, N. C. 2004. Differences in etiology affect mefenoxam efficacy and the control of pink rot and leak tuber diseases of potato. Plant Dis. 88:301-307.

52. Taylor, R. J., Salas, B., Secor, G. A., Rivera, V., and Gudmestad, N. C. 2002 Sensitivity of North American isolates of Phytophthora erythroseptica and Pythium ultimum to mefenoxam (metalaxyl). Plant Dis. 86:797-802.

53. Torres, H., Martin, C., and Henfling, J. 1985. Chemical control of pink ro of potato (Phytophthora erythroseptica Pethyb.). Am. Potato J. 62:355-361.

54. Vegh, I., Leroux, P., Le Berre, A., and Lanen, C. 1985. Detection on Chamaecyparis lawsoniana, 'Ellwoodii' of a strain of Phytophthora cinnamoni resistant to fosetyl-Al. Rev. Hortic. 262:19-21.

55. Vujicic, R., and Park, D. 1964. Behavior of Phytophthora erythroseptica in soil. Trans. Br. Mycol. Soc. 47:455-458.

56. Wicks, T. J., Davoren, C. W., and Hall, B. H. 2000. Fungicidal control of Phytophthora erythroseptica: The cause of pink rot on potato. Am. J. Potato Res. 77:233-240. 